\title{
FEDERAL DISCOVERY IN OPERATION
}

\author{
James A. PIKE* and John W. Willis $\dagger$
}

$I^{1}$ N THE Federal Rules, now a year and a half old, a new philosophy of procedure has emerged in practical form. ${ }^{x}$ To follow an analysis one of us recently adopted, ${ }^{2}$ any system of procedure preparatory to trial has three objects: (I) notice-giving-informing the parties of the general nature of the claims or defences to be litigated; (2) issue-formulation-narrowing the matters in dispute between the parties in order to simplify the trial; and (3) fact-revelation-making it possible for the parties to be familiar before trial with the facts relevant to the case. Under common-law procedure, and to some extent under the codes, the burden of performing the three functions fell almost entirely upon pleading-indeed a faltering workman for the performance of such great tasks. The new Federal Rules of Civil Procedure have supplied pleading with two husky helpmates: the pre-trial hearing under Rule 16 bears much of the burden of issue-formulation; ${ }^{3}$ and the discovery procedure under Rules 26 to 37 , in addition to aiding in issue-formulation, bears most of the burden of factrevelation. Thus notice-giving is the only task which pleading must execute alone. This makes possible a more generalized form of statement than was heretofore appropriate. ${ }^{4}$ As pleadings have become less significant in

*Attorney, Securities and Exchange Commission; Lecturer in Civil Procedure, George Washington University.

$\dagger$ Member of the California Bar.

I The new Federal Rules of Civil Procedure were authorized by Congress in 1934 (48 Stat. 1064 (I934), 28 U.S.C.A. $\$ \S 723$ b, 723c (Supp. I938)) and became effective on September I6, r938 (Rule 86), after three years of work by the Advisory Committee appointed by the court. Dean (now Judge) Charles E. Clark was Reporter for the Committee.

On the movement for the adoption of the Rules and their general scope, see Proceedings of Cleveland Institute on Federal Rules of Civil Procedure 177-82 (A.B.A. 1938); Clark and Moore, A New Federal Civil Procedure: I. The Background, 44 Yale L. J. 387 (1935); Sunderland, The Grant of Rule-Making Power to the Supreme Court of the United States. 32 Mich. L. Rev. III6 (I934).

2 Pike, Cases on New Federal and Code Procedure 57-60 (I939).

${ }^{3}$ See Sunderland, The Theory and Practice of Pre-trial Procedure, 36 Mich. L. Rev. 215 (1937); Pre-trial Hearings and the Assignment of Cases, 33 Ill. L. Rev. 699 (1939).

4 See Status of the Ultimate Fact Test in Pleading under the New Federal Rules, I Fed. Rules Serv. 8a.24 (1939). But cf. McCaskill, Jury Demands in the New Federal Procedure, 85 U. Pa. L. Rev. 315, 325 (1940). 
the pre-trial picture, objections thereto, designed to polish them to perfection, have been viewed with less favor. ${ }^{5}$

Against this general background, the new discovery procedure can be understood. In order to provide a procedure flexible enough to accomplish the objects of fact-revelation and issue-formulation in various types of cases, the new rules have provided several separate but interrelated devices. First, there is the deposition-discovery procedure under Rules 26,30 , and 3I, by which information may be secured from any person having knowledge of relevant facts-either upon oral examination or written interrogatories. Next, by similar means, information to be used in future litigation, or possibly in framing a complaint, may be procured by deposition before action under Rule 27. Third, Rule 33 provides for interrogating the adverse party in writing. Fourth, provision is made for the inspection, copying, and photographing of documents or of real or personal property in the possession or control of the adverse party. Fifth, Rule 35 provides for physical and mental examination of parties. And finally in Rule 36 a simple procedure is afforded for securing before trial admissions of facts or of the genuineness of documents.

The first device mentioned-the general deposition-discovery procedure-requires further explanation. Briefly, under the new rules deposition and discovery have been merged. The customary objections to the taking of depositions may now be made only when it is sought to introduce the depositions at the trial. ${ }^{6}$ As a result, pre-trial examination-oral or written ${ }^{7}$-may be had of any person having relevant information; and restrictions on the scope of the examination obtaining under the tradition-

5 Pike, Objections to Pleadings under the New Federal Rules of Civil Procedure, 47 Yale L. J. 50 ( (937).

${ }^{6}$ The types of unavailability which will justify use of the record of the deposition hearing at the trial are outlined in Rule 26 (d) (3):

"The deposition of a witness, whether or not a party, may be used by any party for any purpose if the court finds: $I$, that the witness is dead; or 2, that the witness is at a greater distance than 100 miles from the place of trial or hearing, or is out of the United States, unless it appears that the absence of the witness was procured by the party offering the deposition; or 3 , that the witness is unable to attend or testify because of age, sickness, infirmity, or imprisonment; or 4, that the party offering the deposition has been unable to procure the attendance of the witness by subpoena; or 5 , upon application and notice, that such exceptional circumstances exist as to make it desirable, in the interest of justice and with due regard to the importance of presenting the testimony of witnesses orally in open court, to allow the deposition to be used."

7 The procedure for oral examination is outlined in Rule 30 , the procedure for written interrogatories in Rule $3 \mathrm{I}$. The choice is with the discoverer, but the court may on motion of the discoveree change the mode of examination. Rules 30 (b), 30 (d), 3 I (d). Cf. Rule 27 (a) (3), providing that the court shall decide initially the mode of examination in depositions before action. 
al discovery procedure have been swept away. Should the persons so examined be available at the trial, the record of their pre-trial examination normally serves only a discovery purpose; but should any of the persons become unavailable, the record may be used in the trial under the circumstances listed in Rule $26(\mathrm{~d}) .^{8}$

About a year ago we discussed the general nature of the new procedure and the changes it wrought in existing limitations upon fact-gathering devices, pointing out some small defects in the procedure and expressing some large hopes for its effectiveness in renovating federal civil procedure. ${ }^{9}$ Since that time the bright tools have been tried by fire: they have been blackened and sometimes dulled in the work of litigation. What was then only a philosophy and a hope has in action played an important part in the trial-preparation of hundreds of litigants, the wide use of the procedure being reflected by opinions in over a hundred cases. It is the purpose of the present article to project these decisions against the general pattern we previously sketched. It is intended both as a practical guide to the practitioner making use of these new tools and as a factual basis for the consideration of changes in the language of Rules 26 to $37 .^{10}$

Before considering specific problems which have been affected by the cases, two broad trends should be noted: the first dealing with the relation between discovery procedure and the procedure for obtaining a bill of particulars, and the second with the relation between the two methods of testimonial discovery-depositions under Rule 26 and interrogatories under Rule 33.

Rule I2(e) provides that "a party may move for a more definite statement or for a bill of particulars of any matter which is not averred with sufficient definiteness or particularity to enable him properly to prepare his responsive pleading or to prepare for trial." In terms then, this motion overlaps with the discovery machinery as a means of pre-trial fact-gathering. But the motion for bill of particulars has long ago been proved to be both an ineffective method of procuring precise facts, and a technique susceptible of use as a dilatory device. ${ }^{\mathrm{Ix}}$

${ }^{8}$ See note 6 supra.

9 Pike and Willis, The New Federal Deposition-Discovery Procedure, 38 Col. L. Rev. II79, I436 (1938). Some other phases of the subject are treated in Pike, The New Federal Deposition-Discovery Procedure and the Rules of Evidence, 34 Ill. L. Rev. I (I939).

ro The power of the Supreme Court to amend the rules was established by a minor amendment transmitted to Congress on January 2, I940. The Advisory Committee, which met in December and proposed the one change, is giving careful consideration to other suggestions for amendment.

${ }^{x}$ See Remarks of Judge Charles E. Clark, Proceedings of the New York Symposium on Federal Rules of Civil Procedure 242-3 (A.B.A. I938); and Pike, op. cit. supra note 5, at 62-5. 
While it is unfortunate that the new rules perpetuate this motion at all, it is reassuring to find that in numerous decisions last year the district judges have practically read out of the rule the phrase "to prepare for trial"'s2 and have in effect limited the remedy to the function of assisting the defendant in preparing his answer. ${ }^{{ }^{13}}$ This readiness to require the movant to rely upon discovery is based upon the broad scope of examination afforded a discoveror. Paradoxically, however, a number of decisions have used this same reason as a basis for permitting the use of a motion for a bill of particulars as a means of trial-preparation; they argue that if a broad scope of examination is permitted under the rule dealing with discovery, why should it not be permitted under the rule dealing with a motion for a bill of particulars? ${ }^{14}$ But in most instances the courts have been consistently referring those who move for particulars to the more effective and appropriate remedies afforded by Rules 26 to 37 .

As to the second general trend, it should be noted that the rules provide two testimonial discovery devices: first, the regular deposition procedure under Rules 26,30 , and 3 I (to which is assimilated the deposition before action under Rule 27); and second, interrogatories to parties under Rule 33. The latter rule, while apparently intended as an alternative or supplement to the more extensive deposition rules, is silent as to the scope of inquiry. But the new rules had been in force only two weeks when Judge Ford ruled that the methods must be construed together and that the

${ }^{12}$ E.g., Brinley v. Lewis, 27 F. Supp. $3_{3} 3$ (M.D. Pa. I939); Jessup \& Moore Paper Co. v. West Virginia Pulṕ \& Paper Co., 25 F. Supp. 598 (Del. I938); Coca Cola Co. v. Marbert Products Co., 2 Fed. Rules Serv. r2e.23I (E.D. N.Y. x939); Pearson v. Hershey Creamery Co., 3o F. Supp. 82 (M.D. Pa. I939); United States v. Schine Chain Theatres, Inc., 2 Fed. Rules Serv. I2e.23 (W.D.N.Y. Jan. I7, I940).

13 Interestingly enough, a recent decision has indicated that a motion for bill of particulars should be used for this latter purpose in preference to taking a deposition before answer. Pirnie v. Andrews, 2 Fed. Rules Serv. 26a.I64 (S.D. N.Y. I939). According to Rule 26(a) a deposition may be taken after answer upon notice; but leave of court must be sought to take one before answer. Yet it would seem that, rather than a bill of particulars, interrogatories under Rule 33 (which may be filed as soon as the action is instituted) would provide the defendant with the best possible means of preparing his answer. Interesting in this connection is the suggestion of Judge Clark: "If any of you in the federal courts are proposing to move for a more definite statement, I would suggest that you hesitate and say, 'Will I get it,' and eventually decide to proceed under the rules, for example, to proceed under Rule 33, which provides very simply for questions to be addressed to the opposing party without any formality whatever." Proceedings of New York Symposium on Federal Rules of Civil Procedure 242-3 (A.B.A. I939).

${ }^{4}$ E.g., Teller v. Montgomery Ward \& Co., 27 F. Supp. 938 (E.D. Pa. I939); Mulloney v. Federal Reserve Bank of Boston, 26 F. Supp. 148 (Mass. 1938). In the Teller case the court went so far as to allow defendant to use a motion for bill of particulars to procure names of witnesses, because they could be obtained by discovery. 
scope of examination under Rule 33 was not to be limited by the restrictions that courts had built around Equity Rule 58, but was to be as broad as that provided in Rule 26 (b) for depositions ${ }^{\mathrm{x}}$-a view which, with a recent exception, ${ }^{16}$ has been generally applied..$^{17}$

\section{"FISHING EXPEDITIONS"}

It was in the scope of examination that the new rules effected the most profound change, and it is with this subject that most of the past year's decisions are concerned. Naturally enough, it is in this field that most of the conflicts of interpretation have developed.

When the new rules went into effect it was assumed that an end was put to the time-honored stricture on "fishing expeditions" imposed by the rule that a party might not discover facts concerning his opponent's case..$^{88}$ The rules were given an encouraging send-off on this point by the opinion of Judge Moscowitz in one of the first cases, in which he said that "It will not avail a party to raise the familiar cry of "fishing expedition." "rs On the whole, the federal courts have tended to agree with this statement. Several decisions have expressly held that a party may inquire into his opponent's case, ${ }^{20}$ one court going so far as to say that discovery under the new rules affords "the privilege of compelling either or both parties to disclose before trial the detailed items of evidence." 2 In view of the extent to which the phrase had become commonplace in discovery cases before the new rules, the failure of the courts to refer to "fishing expeditions" in the many cases of the past year is quite commendable.

Of course it would have been contrary to human nature, particularly to judicial nature, if the adoption of the new practice had swept away all vestiges of the old rule. In fact, the provisions of Rules $3 \circ(\mathrm{b})$ and (d) and

${ }^{15}$ Nichols v. Sanborn Co., 24 F. Supp. 908 (Mass. I938), quoting 2 Moore, Federal Practice $\S 22.02$ (I938).

${ }^{26}$ See Coca Cola Co. v. Dixi-Cola Laboratories, 30 F. Supp. 275 (Md. I939).

${ }^{27}$ See, e.g., B.B. Chemical Co. v. Cataract Chemical Co., 25 F. Supp. 472 (W.D. N.Y. r938); Landry v. O'Hara Vessels, 29 F. Supp. 423 (Mass. I939); Lanova Co. v. Nat'l Supply Co., 29 F. Supp. xig (W.D. Pa. x939).

${ }_{18}$ Pike and Willis, op. cit. supra note 9, at $1436-43$. Typical of the former rule is the opinion of Judge Lindley in the recent case of Indianapolis Amusement Co. v. Metro-Goldwyn-Mayer Dist. Co., go F. (2d) 732, 734 (C.C.A. 7th r937): "A bill will not lie to pry into the case of an adversary, to learn its strength or weakness. A discovery sought upon suspicion or vagueness is of a fishing character and will be dismissed."

${ }^{29}$ Laverett v. Continental Briar Pipe Co., 25 F. Supp. 80 (E.D. N.Y. I938).

${ }^{20}$ Newcomb v. Universal Match Co., 25 F. Supp. I69 (E.D. N.Y. I938); Nichols v. Sanborn Co., 24 F. Supp. 908 (Mass. I938); McInerney v. William P. McDonald Construction Co., 28 F. Supp. 557 (E.D. N.Y. 1939).

${ }^{2 t}$ Judge Porterie, in Dixon v. Sunshine Bus Lines, 27 F. Supp. 797 (W.D. La. 1939). 
3 I (d), which permit the court to limit or terminate an examination when necessary to "protect the party or witness from annoyance, embarrassment, or oppression," clearly left an opening for some of the old limitations. The presumption, however, has been reversed. Previously, inquiry into the other party's case was suspect, and it was allowed only in exceptional cases. Today, practically any line of questioning is prima facie allowable in the absence of some affirmative showing of "annoyance, embarrassment, or oppression."

Examination of the cases in which motions to limit or forbid examination have been passed upon indicates that on the whole the courts have recognized this shift in emphasis. As Judge Moscowitz said in the case just quoted, "It was not intended that they [Rules $30(\mathrm{~b})$ and $30(\mathrm{~d})]$ be made the basis of an application to the Court in every case."22 Such motions are not looked upon with much favor, especially where they are made before the taking of the deposition has commenced; ${ }^{23}$ in fact, they are generally denied except where some definite prejudice is shown. ${ }^{24}$ No judge has yet attempted to limit discovery by deposition or interrogatory to facts supporting the case of the discoveror.

Particularly interesting is an opinion of Judge Nields, rendered in November, I939. The action, one by the government for the recovery of taxes for illegal diversion of alcohol, had been pending for five years and no answer had yet been filed. After the new rules became effective the defendant served interrogatories on the government. The latter objected on the ground that to answer the interrogatories would be to give away part of the government's case since it would require the disclosure of the evidence by which it was intended to show knowledge of the defendant's offcers. Judge Nields overruled the objections, saying that "under the new rules the scope of answers to interrogatories may vary with the special circumstances of the case," and that the defendant, needing the specific information asked for to enable him to answer, was entitled to it. ${ }^{25}$

${ }_{22}$ Laverett v. Continental Briar Pipe Co., 25 F. Supp. 80 (E.D. N.Y. r938).

${ }^{23}$ Stankietvicz v. Pillsbury Flour Mills Co., 26 F. Supp. 1003 (S.D. N.Y. r939); Nekrasoff v. United States Rubber Co., 27 F. Supp. 953 (S.D. N.Y. I939); Newcomb v. Universal Match Co., 27 F. Supp. 937 (E.D. N.Y. I939); Spotts v. O'Neil, 2 Fed. Rules Serv. 3ob.3I (S.D. N.Y. I939); Piccard v. Sperry Co., 30 F. Supp. I7x (S.D. N.Y. I939); Zuckerman v. Pilot, 2 Fed. Rules Serv. 3 ob.3I (S.D. N.Y. I940).

${ }^{4}$ Goldberg v. Raleigh Manufacturers, 28 F. Supp. 975 (Mass. 1939); Union Central Life Ins. Co. v. Burger, 27 F. Supp. 556 (S.D. N.Y. I939); Unlandherm v. Park Contracting Co., 26 F. Supp. 743 (S.D. N.Y. 1938 ); and see cases cited in note 23 supra. Cf. Eastern States Petroleum Co. v. Asiatic Petroleum Co., 27 F. Supp. I2I (S.D. N.Y. I938) (prejudice to deponent shown).

25 United States v. American Solvents \& Chemical Co. of Calif., 30 F. Supp. Io7 (Del. I939). 
One of the chief arguments against the "fishing expedition" objection is the idea that discovery is mutual-that while a party may have to disclose his case, he can at the same time tie his opponent down to a definite position. ${ }^{26}$ A recent decision, however, deals this idea a rather unexpected blow. The defendant in a patent suit was proceeding to take the plaintiff's deposition. The plaintiff moved for an order forbidding inquiry into the dates on which the invention was made or reduced to practice, unless the defendant simultaneously disclosed the date and identity of any prior uses on which it intended to rely as anticipatory. Rule $3 \circ(\mathrm{b})$ prescribes that the court, among other things, may order "that the parties shall simultaneously file specified documents or information enclosed in sealed envelopes to be opened as directed by the court." This principle of mutual disclosure is well established in patent litigation ${ }^{27}$ and has been applied under the new rules when parties have requested bills of particulars ${ }^{28}$ or answers to interrogatories, ${ }^{29}$ even though the rules dealing with bills of particulars and interrogatories (unlike Rule $3 \circ(\mathrm{b})$ dealing with depositions) do not expressly sanction the practice. Yet the court denied the motion, brushing aside as without merit the contention that the City of Milwaukee, the defendant in the action, might practice a fraud on the plaintiff. ${ }^{30}$ Granting that, as the court said, the rules should be given a liberal construction, allowance of the plaintiff's motion would have been entirely in line with the policy of the new procedure..$^{30 a}$

The extent to which the "fishing expedition" argument has been devitalized is strikingly illustrated by a line of cases in the Eastern and Southern Districts of New York in which the plaintiff in a personal injury action sought discovery of statements gathered by the opposite party or his insurer after the accident-in some instances apparently after the institution of suit. ${ }^{30 b}$ The first case, Bough v. Lee, ${ }^{300}$ is also of interest in that it indicates that the course of discovery does not run as smoothly as might have been hoped. The defendant's insurer had obtained statements from the plaintiff and the defendant following the automobile collision which gave rise to the suit. Unable to obtain them from the defendant, who did

${ }^{26}$ See Pike and Willis, op. cit. supra note 9, at $1437-8$.

${ }^{27}$ Dick v. Underwood Typewriter Co., 235 Fed. 300 (S.D. N.Y. I9I6).

${ }^{28}$ Teller v. Montgomery Ward \& Co., 27 F. Supp. 938 (E.D. Pa. I939).

${ }^{29}$ Ibid.; Babcock \& Wilcox Co. v. North Carolina Pulp Co., 25 F. Supp. 596 (Del. I938).

${ }^{30}$ Chemo-Mechanical Water Improvement Co. v. Milwaukee, 29 F. Supp. 45 (E.D. Wis. 1939).

${ }^{302}$ Cf. Spotts v. O'Neil, 2 Fed. Rules Serv. 30b.37 (S.D. N.Y. r939).

${ }^{30 b}$ See Discovery of Statements and Documents Obtained after Claim Has Accrued, 2 Fed. Rules Serv. 26b.2II (I940).

${ }^{300} 26$ F. Supp. 1000, 28 F. Supp. 673, 29 F. Supp. 498 (S.D. N.Y. r939). 
not have them in his possession, ${ }^{3 x}$ the plaintiff served a notice to take the deposition of the insurance company. The defendant's motion to forbid inquiry as to the statements was denied, Judge Leibell saying that "the matter sought upon the examination may be relevant and material upon the trial, either on the cross-examination or redirect examination of the parties themselves." ${ }^{32}$ The matter was not to end there, however. A subpoena duces tecum having been issued, a motion to vacate it was made and denied; appeal was taken from the order denying the motion, and application made for a stay; the latter being denied, the representatives of the insurance company testified that they did not have the statements, and that these were either at their New York office or in the possession of their New York or Washington attorneys. The deposition of a representative of the New York office was then taken with no more success. The attorney for the insurance company, although present at the taking of the deposition, refused to say whether he had a copy of the plaintiff's statement, stating that he attended as an attorney and not as a witness. Thereupon his deposition was noticed for taking. He moved to vacate or limit the examination, claiming the matter to be privileged. Judge Leibell denied the motion in strong terms, and that ended the matter. ${ }^{33}$

Perhaps the most disturbing feature about the Bough case is its revelation of how a wealthy litigant may by subterfuge entirely defeat the purpose of the discovery procedure. The plaintiff in that case apparently had sufficient funds and was sufficiently interested in obtaining inspection of the statements to continue pursuit of the defendant. A less fortunate litigant might well be forced to abandon his search before he has even had an opportunity to bring the sanctions of Rule 37 into play.

The Bough case was followed in Kulich v. Murray, ${ }^{34}$ an automobile collision case also decided in the Southern District of New York. With the object of looking into statements obtained by the insurer of one of the defendants after the accident, the plaintiff served notice upon the insurer for the taking of depositions. Since the investigation was allowed chiefly upon the ground that the plaintiff was seeking to obtain information tending to show an agency relationship between the two defendants, the case is perhaps not as strong against the "fishing expedition" rule as the Bough case or the later decision in Price v. Levitt. ${ }^{35}$ In the Price case the

${ }^{31} 26$ F. Supp. 1000 (S.D. N.Y. 1939). But cf. Marsh v. Mertz, 32 D. \& C. II7 (Pa. Com. Pl. I938) (insurer's possession is party's possession).

${ }^{32}$ Bough v. Lee, 28 F. Supp. 673 (S.D. N.Y. I939).

33 Bough v. Lee, 29 F. Supp. 498 (S.D. N.Y. I939).

3428 F. Supp. 675 (S.D. N.Y. I939).

3529 F. Supp. 164 (E.D. N.Y. 1939). 
plaintiff, her daughter and son-in-law, and her physicians had all given statements to the defendant's insurer before institution of the action, and the plaintiff thereafter attempted to obtain discovery of them by taking the insurer's deposition. Relying upon the two earlier cases, Judge Campbell denied the defendant's motion to vacate the notice of taking, saying that the statements were relevant and might be used in cross-examination of the witnesses.

Consideration of these cases would be incomplete without reference to the question of privilege. The new rules, of course, expressly preserve the question of privilege. ${ }^{36}$ In each case the point was raised and decided adversely to the discoveree. No privilege, it was held, attaches to statements obtained by an insurance company in the course of its own investigation, nor does the matter become privileged by its afterwards being turned over to the attorney for the company or for the insured. The precise question has received little attention in other jurisdictions. A California court has recently held that reports and statements obtained by an insurer were procured for the use of its attorney and were therefore fully privileged. ${ }^{37}$ Reliance was placed upon an Ohio decision which involved a report made by the insured to the insurer and turned over by the latter to its attorney. The latter court held the matter privileged as constituting a communication between the insurer and its attorney. ${ }^{88}$ New York trial courts have recognized that there is no privilege between insurer and insured, ${ }^{39}$ but a statement made directly by the insured to the attorney for the company has been held privileged on the theory that the latter was actually the attorney for the policy-holders. ${ }^{40}$ The federal decisions, however, seem in accord with Dean Wigmore's statement of the scope of the attorney-client privilege. ${ }^{4 x}$ According to that theory, only direct communications from client to attorney are privileged. If a document came into existence as a communication from the client to the attorney, it is privileged; if it was already in existence and was simply turned over to the attorney, it is not. As stated by Judge Leibell, "an attorney is obliged to produce .... . such documents as his client could have been compelled

${ }^{36}$ See p. 315 infra.

${ }^{37}$ New York Casualty Co. v. Superior Court, 85 P. (2d) 965 (Cal. App. 1939); cf. Gillespie Grain Co. v. Wacowich, [1932] 3 D.L.R. 255 (Alta. S. Ct.); Davenport Co. v. Pa. R. Co., i66 Pa. 480, 3r Atl. 245 (r895).

${ }^{8}$ In re Klemann, $x_{32}$ Ohio St. 187,5 N.E. (2d) 492 (I936).

39 Cote v. Knickerbocker Ice Co., 660 Misc. 658, 290 N.Y. Supp. 483 (x936).

${ }^{40}$ Neugass v. Terminal Cab Co., I39 Misc. 699, 249 N.Y. Supp. 63I (I93I).

${ }_{47} 5$ Wigmore, Evidence $\S 2318$ (2d ed. I923). 
to produce." ${ }^{22}$ Of course, there can be no question of privilege as to statements made by persons not related to the insurer or attorney.

The federal cases apparently do not give a party carte blanche to inspect the files of his opponent or his opponent's insurance carrier hoping that he may turn up some material evidence that he has not been able to acquire by his own exertions. In each of the decisions discussed above the discoveror was able to show quite clearly just what documents he was after; otherwise his exploration would probably have been regarded as "oppression." Thus in a very recent decision, Judge Moscowitz, passing on the question of "the extent to which the new Rules of Civil Procedure permit the examination by one party of affidavits and similar material secured by the other party by independent investigation incident to the preparation of the case for trial," said:

While the Rules of Civil Procedure were designed to permit liberal examination and discovery, they were not intended to be made the vehicle through which one litigant could make use of his opponent's preparation of his case. To use them in such a manner would penalize the diligent and place a premium on laziness. It is fair to assume that, except in the most unusual circumstances, no such result was intended.43

And Justice Proctor of the District of Columbia Court has denied discovery sought under Rule 34 of statements of eyewitnesses to an accident, saying that "good cause," required by the rule, was not shown, and that the documents would not be admissible in evidence except as a means of contradicting a witness. ${ }^{44}$ Similarly, in a patent case, Judge Nields held that "The new Rules of Civil Procedure were not intended to permit a party to pry into the details of the other party's preparation for trial," and denied a request for production of drawings of certain apparatus relating to defendant's projected defense. ${ }^{45}$ Finally, in four recent cases in the Southern District of New York involving rather unspecific explorations, Judge Coxe called a halt. ${ }^{6} \mathrm{He}$ did not even attempt to distinguish the Bough, Kulich and Price cases $^{47}$ - a distinction he might well have made in view of the specific character of the demands made in the Bough, ${ }_{42}$ Bough v. Lee, 29 F. Supp. 498 (S.D. N.Y. 1939).

${ }_{43}$ McCarthy v. Palmer, 29 F. Supp. 585 (E.D. N.Y. x939); cf. Creden v. Central R. R. Co., 2 Fed. Rules Serv. 33.35I (Jan. 24, I940).

${ }_{44}$ Slydell v. Capital Transit Co., 2 Fed. Rules Serv. 34.4II (D.C. r939); cf. Seals v. Capital Transit Co., 2 Fed. Rules Serv. 34.4II (D.C. I940).

${ }_{45}$ Floridin Co. v. Attapulgus Clay Co., 26 F. Supp. 968 (Del. r939).

${ }^{46}$ Kenealy v. Texas Co., 29 F. Supp. 502 (S.D. N.Y. 1939); Fluxgold v. United States Lines Co., 29 F. Supp. 506 (S.D. N.Y. 1939); Bennett v. Waterman S. S. Co., 29 F. Supp. 506 (S.D. N.Y. I939); Rose Silk Mills v. Ins. Co. of North America, 29 F. Supp. 504 (S.D. N.Y. I939).

47 See pp. 303-5 supra. 
Kulich and Price cases; instead he expressly declined to follow "expressions to the contrary" in those decisions ${ }^{4}$ - even though the Bough and Kulich cases were decided in the same district.

Reserved for later discussion is a problem which naturally arises in the type of case under discussion - the problem of whether relevant information in the discoveree's files which may not be admissible in evidence because of, for example, the hearsay and opinion rules, is a proper subject matter of inquiry. 49

\section{DISCOVERY OF MATTERS WITHIN ONE'S OWN KNOWLEDGE}

Perhaps the greatest divergence in the cases under the new rules has arisen over the question of whether a party seeking discovery from his opponent should be precluded from inquiring into matters within his own knowledge. Federal decisions under old Equity Rule 58 had generally held the inquiry improper..$^{50}$ The flat imposition of such a limitation is, of course, not in keeping with the broad scope of discovery envisaged by the new procedure. The question is not simply one of imposing upon the discoveree without benefiting the discoveror. One of the recognized objectives of the new discovery procedure is the shortening and simplification of trials, and it is obvious that introduction of admissions of the adverse party constitutes a much more expeditious method of disposing of issues than does the production of lengthy testimony; moreover a case based upon admissions is more likely to result in summary judgment than is one which relies upon controverted testimony..$^{\text {Ix }}$ Viewed from this standpoint, the fact that the discoveror himself knows the facts is not controlling. If the inquiry will serve either of the objects of discovery-ascertainment of unknown facts or ease of proof of known facts, it should be permitted; if not, it should be disallowed.

But if in their allowance or denial of discovery of matters within the discoveror's own knowledge, the courts have been moved by such considerations, they have not articulated them clearly. Perhaps we have made a Procrustean bed; but it so happens that, with one possible exception, ${ }^{52}$ all the cases on the question fit into a pattern: In the decisions permitting discovery of facts within the discoveror's own knowledge, inquiry

${ }^{48}$ Kenealy v. Texas Co., 29 F. Supp. 502 (S.D. N.Y. 1939).

49 See p. 309, infra.

so Zolla v. Grand Rapids Store Equipment Co., 46 F. (2d) 319 (S.D. N.Y. r93I); see Pike and Willis, op. cit. supra note 9, at I439.

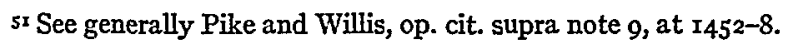

52 United States v. American Solvents \& Chemical Co. of Calif., discussed at p. 302 supra. 
was directed to matters regarding the discoveror's own case; ${ }^{53}$ in those forbidding discovery of facts known to the discoveror, the inquiry related to his opponent's case. ${ }^{54}$

It does not follow, however, that the rule against "fishing expeditions," which denies discovery of the case of one's opponent, has been resuscitated. Discovery of facts unrelated to the discoveror's case is not objectionable if the facts sought are unknown to the discoveror: the trial-preparation purpose of discovery is fulfilled. Discovery as to facts within the discoveror's own knowledge is not objectionable if the facts do relate to the discoveror's case: the proof-expedition purpose of discovery is fulfilled. It is only when the facts sought are both within the movant's knowledge and unrelated to the movant's case that discovery may be objectionable: perhaps neither purpose of discovery would be fulfilled if discovery were permitted.

This analysis reconciles the cases. But it is only fair to point out two considerations which bear somewhat adversely upon it: (I) Much depends upon the meaning accorded the word "case." If a litigant's "case" includes only propositions upon which the litigant has the burden of proof, the limitation upon discovery suggested in the last paragraph is not desirable; securing admissions to expedite the proof of the negative of the opponent's claim or defense is as useful as securing admissions to prove the affirmative of a claim or defense. But if "case" is taken to extend to both affirmative and negative positions, then there is no relevant material which would not be germane to either party's "case." (2) If this is "logicchopping," there is still the practical consideration involved in the mechanics of the summary judgment. ${ }^{55}$ The customary basis for such a judgment is that the opponent has no case, and the latter's admissions as to his own case afford the easiest method of proving that he has none.

Even if the suggested theory is admitted to be the proper rationale of the decided cases, it may prove no serious obstacle to a party desiring admission of facts within his knowledge which relate to his opponent's

53 Nichols v. Sanborn Co., 24 F. Supp. 908 (Mass. I938) (plaintiff may inquire into activities of defendant in patent suit); Benevento v. A. \& P. Food Stores, 25 F. Supp. 424 (E.D. N.Y. 1939) (plaintiff may inquire into facts showing negligence of defendant).

54 B.B. Chemical Co. v. Cataract Chemical Co., 25 F: Supp. 472 (W.D. N.Y. I938) (plaintiff not required to give analysis of defendant's allegedly infringing composition); Babcock \& Wilcox Co. v. North Carolina Pulp Co., 25 F. Supp. 596 (Del. I93 $^{8}$ ) (plaintiff not required to specify acts complained of as infringements); Bailey v. General Sea Foods, 26 F. Supp. $39 \mathrm{r}$ (Mass. I939) (plaintiff not required to specify in what respect defendant was negligent); Norton v. Cooper, Jarrett Co., I Fed. Rules Serv, 26b.23 (N.D. N.Y. I938) (plaintiff may not examine defendant as to plaintiff's operation of vehicle).

$5 s$ As to the intimate relation between discovery and summary judgment under the new rules, see Pike and Willis, op. cit. supra note 9, at $1455^{-8}$. 
case. Such a party might utilize the procedure of Rule 36 and serve his opponent with a request that he admit facts; since the request must be declarative in form, and since the purpose of the notice to admit procedure is to secure admissions, the request must presumably be complied with, even though compliance will result in the admission of facts concerning the admitter's case which were known to the movant when he served the notice to admit. Our earlier suggestion ${ }^{56}$ to this effect has recently been fortified by a decision of Judge Holly in the Northern District of Illinois. Referring to the procedure under Rule 36 , Judge Holly observed:

Nor does it matter that the plaintiff is acquainted with the facts as to which admission is sought. The purpose of the rule is to expedite trial, and to relieve parties of the cost of proving facts which will not be disputed on the trial and the truth of which can be ascertained by reasonable inquiry. 57

\section{DISCOVERY OF MATTERS INADMISSIBLE IN EVIDENCE}

We have just considered the extent to which the courts have tended to apply narrower standards to depositions and interrogatories than would be applicable to testimony in open court. But there is another side to the question. Experience has shown that though much of the matter inquired into in the taking of depositions for discovery purposes is probably inadmissible evidence-hearsay, opinion, and so on, objection is rarely made by counsel..$^{8}$ Suppose, however, that the question is brought to a showdown. Is discovery to be limited to matters admissible in evidence?

The answer to this question should be in the negative. ${ }^{59}$ Clearly, information gained by discovery may be helpful to the party in preparing his case, in anticipating his opponent's position, and in gathering other evidence, even if it might not be used as proof at the trial. And the reasons behind such principles of evidence as the hearsay rule and the rule against opinions are obviously inapplicable to discovery.

Rule 26 itself would seem to indicate the soundness of this position. Rule 26(a) states that "testimony . . . may be taken . . . . for the purpose of discovery or for use as evidence in the action or for both purposes." Rule 26(b) provides for examination "regarding any matter, not privileged, which is relevant to the subject matter involved in the pending action. . . . "Since there is no way of earmarking a deposition in advance as to whether its purpose is discovery or proof, there would seem to be no justification for applying any limitations to the examination other than

${ }^{56}$ This analysis was advanced by the present authors in Inquiry by Deposition into Facts within Discoveror's Own Knowledge, I Fed. Rules Serv. 26 b.23 (1939).

57 Hanauer v. Siegel, 29 F. Supp. 329 (N.D. Ill. I939).

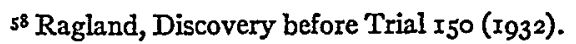

s9 Cf. Remarks of Prof. William W. Dawson, Proceedings of Washington Institute on Federal Rules of Civil Procedure 97 (A.B.A. 1939). 
that stated in the rule itself-the limitation of relevancy, which is clearly broader than the boundaries of admissibility-saving always the power of the court to limit the examination under Rules $30(b)$ and (d) and 3 I(d) for good cause shown. Unpersuasive are state decisions restricting examination to matters admissible in evidence, ${ }^{60}$, for in most states the deposition is still regarded primarily as a means of preserving proof, its discovery functions being only incidental.

Support for the view just outlined is found in a recent decision by Judge Hincks of the District of Connecticut. An action arising out of an airplane crash was brought against two defendants, an air line and a manufacturer. The only ground upon which it was sought to hold the manufacturer was the alleged failure of a certain cylinder. When the air line sought to take the deposition of the manufacturer, the latter contended that the examination should be limited to the condition of the particular cylinder. The court rejected this argument, pointing out that Rule 26(b) does not limit examination to matters relevant to the precise issue, but allows any inquiry relevant to the general subject matter of the actionhere, the crash and its causes. "To the extent that the examination develops useful information," it was said, "it functions successfully as an instrument of discovery, even if it produces no testimony directly admissible." ${ }^{\prime 6 x}$

In support of his argument Judge Hincks pointed out that Rule 26(b) permitted inquiry as to "the identity and location of persons having knowledge of relevant facts," which matter, he said, was "obviously . . . . not directly admissible in evidence."

The Air Lines case is the only one in which the question has been discussed at any length. ${ }^{62}$ Judge Holly, in a recent decision under Rule 33 , directed a defendant to answer certain interrogatories, saying:

I am not determining that the answers will be admissible in evidence. They may or may not be, but if it appears on the trial that the information called for is admissible, having the information in the record will expedite the proceedings. ${ }^{62 a}$

60 E.g., May v. Midwest Refining Co., Io F. Supp. 927 (Me. I935) (mental states, intention); Hughes v. Hughes, $3^{\mathrm{I}}$ Ala. $5^{\mathrm{Ig}}$ (1858) (hearsay); Rooker v. Rooker, 83 Ind. 226 (I882) (hearsay); Wanamaker v. Megraw, I68 N.Y. I25, 6I N.E. II2 (IgoI), rev'd 62 N.Y. Supp. 692 (1900) (conclusions of deponent); The Peterhoff, Fed. Cas. No. II, 024 (S.D. N.Y. x863) (responsiveness of answers); Meadows v. Thomas, I87 Ind. 216, II8 N.E. 8II (19r8) (scope of cross-examination).

6x Lewis v. United Air Lines Transport Co., 27 F. Supp. 946 (Conn. 1939).

6z See Pirnie v. Andrews, 2 Fed. Rules Serv. $26 a .164$ (S.D. N.Y. x939); and cf. Fletcher v. Foremost Dairies, Inc., of New York, 29 F. Supp. 744 (E.D. N.Y. I939); Rose Silk Mills, Inc., v. Insurance Co. of North America, 29 F. Supp. 504 (S.D. N.Y. 1939).

${ }_{622}$ Sears Roebuck \& Co. v. Harrison, 2 Fed. Rules Serv. $33 \cdot 34$ (N.D. Ill. I940). 
In a number of other decisions, however, federal judges have tended to impose evidentiary limitations upon pre-trial examination, apparently without giving much consideration to the distinction between "relevancy" and "admissibility."

But contrary to the Air Lines case is Judge Leibell's statement in Union Central Life Insurance Co. v. Burger" ${ }^{63}$ that "Ordinarily examinations under Rule $26(\mathrm{~b})$ should conform to general rules of admissibility of evidence as tested by Rule 43(a)." In that case, an action to cancel and rescind a policy, the plaintiff insurer served a notice on the defendant beneficiaries for the taking of depositions, specifying the subject of the examination. ${ }^{64}$ It seems apparent that the purpose of the examination was discovery and that the matters to be inquired into were certainly relevant, if not admissible evidence. ${ }^{65}$ While the court refused to limit the scope of the examination except as to one item, ${ }^{66}$ it did so on the ground that the admissibility of the evidence could not properly be determined solely on the pleadings and affidavits, but might better be decided on a motion under Rule 30 (d) after the examination had been commenced, or by objection when the deposition was used at the trial..$^{67}$

Difficulty has also been experienced, particularly in patent cases, with interrogatories relating to matters of opinion. Under old Equity Rule 58 such interrogatories were held improper, ${ }^{68}$ even though the rule was intended as a method of discovery. Under the liberal construction which most courts have given new Rule 33, however, ${ }^{69}$ precedents under the old Equity Rule are not particularly persuasive; and several decisions in patent cases have adopted a pragmatic approach. In Pierce v. Submarine Signal Co., ${ }^{70}$ the plaintiff requested the defendant to disclose the blueprints, drawings, and description of the apparatus made by the defendant

${ }_{63} 27$ F. Supp. 556 (S.D. N.Y. 1939).

${ }_{64}$ This is unnecessary: Bennett v. The Westover, 27 F. Supp. ro (S.D. N.Y. I938).

${ }_{65}$ "..... The physical condition, habits and activities of Dewey D. Burger subsequent to September $30, x_{3} 6$, in so far as they have any bearing upon or are evidence of his physical condition on September 30 th, $x_{93} 6 ; \ldots$. the circumstances, facts and particulars of Dewey D. Burger's last illness in so far as they have any bearing upon, or are evidence of his physical condition on September 30 th, $1936 ; \ldots$ the events, incidents and occurrences on the date of Dewey D. Burger's death, including conversations had by the deceased or by the defendants and conversations in the presence of the deceased and the defendants."

${ }^{66}$ The last item in note 65 supra. $\quad{ }^{67} \mathrm{On}$ this point the Lewis case is in accord.

${ }^{68}$ Batdorf v. Sattley Coin Handling Mach. Co., 238 Fed. 925 (E. D. Mich. I9r6), Gennert v. Burke \& James, 23I Fed. 998 (S.D. N.Y. 1916); Earp Thomas Farmogerm Co. v. Stimuplant Laboratories, Inc., $3^{8}$ F. (2d) 691 (E.D. N.Y. I930).

${ }^{69}$ See Nichols v. Sanborn Co., 24 F. Supp. 908 (Mass. r938).

${ }^{70} 25$ F. Supp. 862 (Mass. I939). 
"which the defendant considers to be most nearly like" the plaintiff's apparatus. The defendant objected on the ground that the interrogatory called for facts based upon the defendant's opinion. Overruling the defendant's objection, the court said:

If in fact it is an instrument that the plaintiff contends infringes his patent, then the parties are sooner at issue. If in fact it nowise could be contended to be an infringement of the plaintiff's patent rights, no harm has come to the defendant, and the matter will probably be at an end.

Even stronger is the opinion of Judge Kirkpatrick in Schwartz v. Howard Hosiery Co. ${ }^{7 \mathrm{I}}$ in overruling an objection to the following interrogatory: "Does the drawing forming part of the patent in suit correctly illustrate the fabric described and claimed as your invention?" "Obviously," the court said, "one of the purposes of Rule 33 is to obtain admissions and thus limit the subjects of controversy at the trial and avoid unnecessary testimony and waste of time in preparation. .... The plaintiff's objections to answering this interrogatory seem to me to be the last word in technicality and entirely out of touch with the spirit of the new rules." A similar view has been taken of a plaintiff's attempt by the use of interrogatories to sound out the basis of the defendant's contentions. ${ }^{72}$ Several other patent decisions, however, taking a conservative view, hold that interrogatories calling upon a party to compare devices with patent claims or to construe a patent are improper. ${ }^{73}$ These cases may be justifiable on the ground that in the particular situation an answer would have been of no substantial value,,$^{74}$ but it is to be hoped that they will not be made a precedent for a wooden rule to the effect that interrogatories as to matters of opinion are barred regardless of whether or not an answer might expedite the litigation.

Are matters of opinion proper subjects of interrogatories where requests for admissions are filed under Rule 36 ? The rule refers to "relevant matters of fact,"7s but the reasons behind the decisions in the Pierce and

${ }^{71} 27$ F. Supp. 443 (E.D. Pa. I939).

72 McInerney v. Wm. P. McDonald Construction Co., 28 F. Supp. 557 (E.D. N.Y. I939).

${ }^{73}$ Stanley Works v. C. S. Mersick \& Co., I Fed. Rules Serv. 33.313 (Conn. r939); Boysell Co. v. Colonial Coverlet Co., 29 F. Supp. I22 (E.D. Tenn. I939); Babcock \& Wilcox Co. v. North Carolina Pulp Co., 25 F. Supp. 596 (Del. r938); Teller v. Montgomery Ward \& Co., ${ }_{27}$ F. Supp. 938 (E.D. Pa. r939); Lanova Co. v. Nat'l Supply Co., 29 F. Supp. Irg (W.D. Pa. 1939); Nakken Patents Co. v. Rabinowitz, 2 Fed. Rules Serv. 33.319 (E.D. N.Y. r940); cf. Thomas French \& Sons, Ltd., v. Carleton Venetian Blind Co., 2 Fed. Rules Serv. 33.342 (E.D. N.Y. 1939).

74 "An answer of the defendants in no proper way would tend to limit their testimony." Lanova Co. v. Nat'l Supply Co., 29 F. Supp. Ir9 (W.D. Pa. 1939).

75 "... . a party may serve . . . a written request for the admission . . . of the truth of any relevant matters of fact ...." Rule $36 a$. 
Schwartz cases $^{76}$ apply even more strongly to the procedure under Rule $3^{6}$, the whole purpose of which is, as the rule itself states, the obtaining of admissions. The question has not yet been squarely passed upon, but the compendious request which Judge Moscowitz sustained in Walsh v. Connecticut Mutual Life Insurance Co. ${ }^{77}$ includes many statements which would certainly be considered matters of opinion if asked of a partywitness at the trial. For example, the plaintiff was asked to admit that

The death of Samuel A. Walsh resulted, directly or indirectly, from various causes, including:

a) Alcoholism

d) Delirium tremens

b) Acute alcoholic poisoning

e) Pneumonia

c) Chronic alcoholic poisoning

and further that certain language used by decedent, which brought about a fatal brawl, was "offensive," "disorderly," "abusive," or "insulting."

Whatever may be the rule as to discovery of a testimonial nature, it seems fairly clear that discovery of documents and other things under Rule 34 is limited to matters admissible in evidence. The rule itself so states: the matter to be produced must "constitute or contain evidence material to any matter involved in the action. ...." Regardless of the reason for this narrower limitation-whether a fear of the unlawful search and seizure clause or some related notion as to the sanctity of a person's papers $^{78}$-the rule itself is unequivocal. Interesting in this connection, however, is Floridin Co. v. Attapulgus Clay $\mathrm{Co}^{79} \mathrm{In}$ an action for infringement of a patent, the defendant set up prior invention by one Fuller. The plaintiff requested the defendant to produce an application filed by Fuller. The application was not relevant, since it was filed after the application for the plaintiff's patent, but the court, feeling that it might have some bearing on Fuller's credibility or his interest in the case or his relationship with defendant, ordered the defendant to turn it over to the plaintiff's counsel so that the latter might point out to the court any passages he felt material. Counsel was cautioned not to reveal the contents of the document to his client or any other person. But when the defendant abandoned any defense based on the Fuller invention the court

${ }_{76}{ }_{24}$ F. Supp. 908 (Mass. 1938) and 25 F. Supp. 862 (Mass. I939), respectively.

7726 F. Supp. 566 (E.D. N.Y. 1939).

${ }_{78}$ ". . . . if the rule were construed as conferring a right to inspect immaterial documents I should doubt its validity." Caffey, D. J., in United States v. Aluminum Co. of America, 26 F. Supp. 7 II (S.D. N.Y. I939); see People ex rel. Lemon v. Supreme Court, 245 N.Y. 24 ${ }^{5} 6$ N.E. 84 (1927).

7926 F. Supp. 968 (Del. I939). 
ordered the documents returned, saying that they could no longer have any bearing on the case. ${ }^{80}$

Just how the question of materiality and admissibility of documents is to be determined is not entirely settled. Judge Moscowitz has held that "it is sufficient that the party seeking discovery establish that it is reasonably probable that the documents sought to be examined constitute or contain material evidence." A stricter requirement, he said, "might compel a party to know what was in the documents before he had seen them." the question of materiality must be determined by the court upon examination of the particular documents sought. ${ }^{82}$ The situation in that case, however, was a peculiar one, the inspection being sought during not before the trial of a protracted anti-trust action, so that the burden on the judge was not as great as if the case were still in the pre-trial stage.

Three very recent decisions establish that the motion for production of documents must show by statement of facts and not by mere conclusions that the documents sought contain material and admissible evidence. . $^{2 a}$

In connection with Rule 34 it is worth while to revert to the cases discussed above in which discovery of statements of witnesses and parties was sought. It is interesting to notice that in the three cases allowing such discovery $^{83}$ the statements were not sought under Rule 34 but by subpoena on the taking of depositions under Rule 45 , while, with one exception, ${ }^{84}$ the cases disapproving of such inquiry involved proceedings under Rule $34 .{ }^{85}$ The decisions themselves do not recognize any distinction be-

8o Floridin Co. v. Attapulgus Clay Co., 2 Fed. Rules Serv. 34.4I (Del. r939).

8r Beler v. Savarona Ship Co., 26 F. Supp. 599 (E.D. N.Y. I939).

82 United States v. Aluminum Co. of America, 26 F. Supp. 7 II (S.D. N.Y. 1939).

${ }^{82 a}$ Thomas French \& Sons, Itd., v. Carleton Venetian Blind Co., 2 Fed. Rules Serv. 34.II (E.D. N.Y. r939); Sonken-Galamba Co. v. Atchison \& C. R. Co., 2 Fed. Rules Serv. 34.II (W.D. Mo. I939); Radtke Patents Co. v. Rabinowitz, 2 Fed. Rules Serv. 34.II (E.D. N.Y. I940).

$8_{3}$ Bough v. Lee, 29 F. Supp. 498 (S.D. N.Y. 1939); Kulich v. Murray, 28 F. Supp. 675 (S.D. N.Y. I939); Price v. Levitt, 29 F. Supp. I64 (E.D. N.Y. I939). For discussion of these cases see pp. 303-5 supra.

${ }^{84}$ Rose Silk Mills v. Ins. Co. of North America, 29 F. Supp. 504 (S.D. N.Y. I939).

${ }_{85}$ Kenealy v. Texas Co., 29 F. Supp. 502 (S.D. N.Y. I939); Fluxgold v. United States Lines Co., 29 F. Supp. 506 (S.D. N.Y. I939); Bennett v. Waterman S.S. Co., 29 F. Supp. 506 (S.D. N.Y. 1939); McCarthy v. Palmer, 29 F. Supp. 585 (E.D. N.Y. 1939); Slydell v. Capital Transit Co., 2 Fed. Rules Serv. 34.4II (D.D.C. I939); Floridin Co. v. Attapulgus Clay Co., 26 F. Supp. 968 (Del. I939); cf. Murphy v. New York \& P.R.S.S. Co., I Fed. Rules Serv. 34.34 (S.D. N.Y. I939). 
tween the two modes of proceeding, and it would seem anomalous if such a distinction were to be made. In fact, Judge Caffey has said that

Rule 34 defines the authority of the court. Rule 45 (b) defines the authority of the clerk. The two rules relate to the same subject. Obviously they must be construed in pari materia. ${ }^{86}$

But there seems to lurk an implication behind the decisions that the courts will look more favorably upon an attempt to inspect documents in the course of an examination by deposition than on an application under Rule 34 for production of the same documents. To be sure, the court in two of the cases found it advisable to say that the statements involved might be admissible on cross or redirect examination, ${ }^{87}$ but this was not enough to satisfy other judges when application was made under Rule $34^{.88}$

\section{PRTVILEGE}

However the matter may be determined as to other exclusionary principles of evidence, it is made clear by the rules that all objections of privilege are preserved. ${ }^{89}$ The policies behind the various privileges are, of course, different from those supporting other evidentiary limitations, so the fact that objections of this nature are still valid has little bearing on the propriety of applying the other rules of evidence.

Questions of privilege have so far presented no difficult problems except perhaps in the insurance company cases discussed above, ${ }^{90}$ but other interesting rulings have been made. In Pollen $v$. Ford Instrument $C o .^{9 \mathrm{x}}$ a motion for inspection of drawings of apparatus manufactured by the defendant was denied on a showing that the apparatus was made under an order of secrecy by the Navy Department and that disclosure was opposed by the Secretary of the Navy as detrimental to the national defense. In another case Judge Watson refused to compel a party (under Rule 34) to consent to inspection of World War Draft records relating to him, on the ground that the Selective Service Regulations made such records confidential and that the court could not require the party to waive his privilege. ${ }^{918}$ And in an action on a fire insurance policy, disclosure of the

${ }^{86}$ United States v. Aluminum Co. of America, I Fed. Rules Serv. 45b.3II (S.D. N.Y. 1939).

${ }^{87}$ Bough v. Lee, 29 F. Supp. 498 (S.D. N.Y. I939); Price v. Levitt, 29 F. Supp. I64 (E.D. N.Y. (1939).

${ }^{88}$ Slydell v. Capital Transit Co., 2 Fed. Rules Serv. 34.411 (D.D.C. x939); Kenealy v. Texas Co., 29 F. Supp. 502 (S.D. N.Y. 1939).

${ }^{89}$ See Rules 26(b) and 34.

90 Pp. 303-5 supra. $\quad 926$ F. Supp. 583 (E.D. N.Y. I939).

${ }_{92 \mathrm{a}}$ Federal Life Ins. Co. v. Holod, 2 Fed. Rules Serv. 34.42 (M.D. Pa. I940). 
names of the defendant's witnesses was refused on the request of the district attorney, who stated that he intended to press an arson charge and that the disclosure of the evidence of the case would enable the plaintiff to "frame" an alibi.".

\section{RELEVANCY}

Whether or not material sought by the various discovery devices must be admissible as evidence, there is no doubt that it must be "relevant." Relevancy, however, is not always easy to determine when the case is still in the pleading stage. Consequently, we suggested in our earlier articles that the idea of relevancy should be treated broadly-that inquiry should be foreclosed only if it clearly appeared that the matter could not be relevant. ${ }^{93}$ This theory has been clearly stated by Judge Leibell in Union Central Life Insurance Co. v. Burger. ${ }^{94}$

On the whole, the notion of relevancy has been given a fairly liberal interpretation. ${ }^{95}$ Some discordant notes have been sounded, however, particularly in connection with the question of damages. There is old law to the effect that discovery as to the amount of damages is premature in advance of determination of the question of liability..$^{96}$ It seems clear enough that such a view is not in keeping with the theory of the new procedure. Disclosure probably will not injure the party, and to say that the facts are not "relevant" until it has been determined that damages are in order, is, in effect, an assumption of the stultifying position that matter supporting any one element of a claim is irrelevant until the other elements are established. A number of cases-particularly patent suits-have carried over the old view, apparently without much consideration. ${ }^{97}$ Contrary in theory, however, is the strong opinion in Foxv. House. ${ }^{98}$ In an

92 Penn. v. Automobile Ins. Co., 27 F. Supp. 336 (Ore. r939).

93 Pike and Willis, op. cit. supra note 9, at I442; Pike, op. cit. supra note 9, at 3-4.

9427 F. Supp. 556 (S.D. N.Y. 1939).

95 Cf. Thompson v. Oil Refineries, 27 F. Supp. I23 (W.D. La. I939); Berke v. United Paperboard Co., 26 F. Supp. 412 (S.D. N.Y. I938); Unlandherm v. Park Contracting Co., 26 F. Supp. 743 (S.D. N.Y. 1938). But cf. Wadlow v. Humberd, 27 F. Supp. 210 (W.D. Mo. I939), discussed at pp. 324-6 infra.

${ }^{96}$ Munger v. Firestone Tire \& Rubber Co., 26I Fed. 92I (C.C.A. 2d rgrg), cert. den. 252 U.S. 582 ( 1920$)$ (damages held not "in issue"). But cf. Sinclair Refining Co. v. Jenkins Petroleum Co., 289 U.S. 689 ( 1933 ) disapproving the Munger case.

97 Boysell Co. v. Colonial Coverlet Co., 29 F. Supp. 122 (E.D. Tenn. r939); Looper v. Colonial Coverlet Co., 29 F. Supp. I25 (E.D. Tenn. r939); Unlandherm v. Park Contracting Co., 26 F. Supp. 743 (S.D. N.Y. I938) (patent cases); O’Rourke v. RKO Radio Pictures, 27 F. Supp. 996 (Mass. r939). Contra: Berke v. United Paperboard Co., 26 F. Supp. 4r2 (S.D. N.Y. 1938$)$.

${ }_{98}^{8} 29$ F. Supp. 673 (E.D. Okla. I939). 
action for an accounting, the plaintiff sought to obtain discovery as to the items of the account, the defendant objecting on the ground that the right to the accounting had first to be determined. Judge Rice, overruling the objection, stated that the rules were intended to facilitate preparation on all phases of the case; that piecemeal discovery would block a speedy determination of the litigation; and that the plaintiff should be permitted to ascertain if an accounting would be worth while.99

Somewhat narrower ideas of relevancy are exhibited in the cases involving discovery of documents under Rule 34-a fact which is not surprising in the light of history. ${ }^{100}$ It has already been pointed out that the insurance company cases were not decided under that rule, ${ }^{\text {ror }}$ and that the Floridin case, discussed above, ${ }^{102}$ is irregular. But the scope of discovery under Rule 34 is clearly broader than that under old Equity Rule 58, which referred to "documents containing evidence material to the cause of action or defense of" the moving party, ${ }^{103}$ and it has been held that the fact that discovery had been denied under the old rule is not a bar to discovery under Rule $34^{\text {I04 }}$

Generally a fairly clear showing must be made that the documents sought are material on some issue of the case. ${ }^{\text {tos }}$ Thus, discovery has been denied where the only purpose was to ascertain whether another person was participating in the defense to such a degree that the judgment would be binding on him. ${ }^{\text {106 }}$ Whether Rule 34 permits discovery for the purpose of amending the complaint was questioned in United States v. Doudera, ${ }^{\text {107 }}$ although the documents involved were held material to the issues already framed.

Some nice distinctions have been made with regard to discovery of facts for use in impeachment. A deponent, of course, may be asked questions tending to impeach his own testimony. ${ }^{x 08}$ And, as we have seen, facts may be brought out which might be useful for impeachment or cross-

99 Contra, under the former procedure, O'Brien v. Mackey, 36 F. (2d) 89 (S.D. N.X. I929).

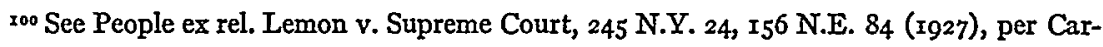
dozo, C.J.

zor P. 3 I4 supra.

${ }^{\text {ros }}$ P. 3I3 supra.

${ }^{103}$ Cf. General Film Co. v. Sampliner, 232 Fed. 95 (C.C.A. 6th I9r6).

xo1 Gielow v. Warner Bros. Pictures, 26 F. Supp. 425 (S.D. N.Y. I938).

ros Floridin Co. v. Attapulgus Clay Co., 26 F. Supp. 968 (Del. r939); Lip Lure v. Bloomingdale Bros., 27 F. Supp. 8 II (S.D. N.Y. I939); see cases in note $82 a$ supra.

${ }^{106}$ Lip Lure v. Bloomingdale Bros., 27 F. Supp. 8II (S.D. N.Y. I939).

${ }^{107} 28$ F. Supp. 223 (E.D. N.Y. I939).

${ }^{108}$ Floridin Co. v. Attapulgus Clay Co., 26 F. Supp. 968 (Del. I939). 
examination of a witness in the trial. ${ }^{\mathrm{x} 9}$ But, according to one holding, this is not proper unless the matter is itself "relevant." Contra is the decision in the Floridin case, already referred to. ${ }^{\mathrm{Ixx}}$

\section{NAMES OF WITNESSES}

Rule 26(b) states that a party might inquire into "the identity and location of persons having knowledge of relevant facts"-in short, into the names of witnesses. ${ }^{\mathrm{xz}}$ The plain language of the rule would seem to insure against any attempt to perpetuate the prevailing contrary view. Yet one decision has already given the phrase what seems to be an unduly narrow interpretation. In Barter v. Eastern Steamship Lines, Inc. ${ }^{\mathrm{Ix} 3}$ the court said:

.... Applying this Rule with the liberality with which it was intended to be applied, I allow and direct the witness to answer all of the questions except: "Q. Mr. Barter, will you give me the names of anybody who knows anything about your accident?" and " $Q$. What are the names of any of the ship's officers or petty officers or members of the crew that know anything about how your accident happened?" I do not believe that the Rule contemplates any such general question.

Fortunately, the rule has been given a more literal application in other cases. ${ }^{114}$ But the arson case referred to above ${ }^{\mathrm{xr}}$ indicates that though the door has been thrown open, the court is still liable to close it to prevent abuse.

ORDERS FOR THE PROTECTION OF PARTIES AND DEPONENTS

It has been pointed out that most of the abuses which might result from the almost unlimited right to take depositions before trial can be avoided by judicious action of the court under Rules $30(\mathrm{~b})$ and (d) and $3 \mathrm{I}(\mathrm{d}) .^{\mathrm{Ir} 6}$ In the cases so far decided, the courts have been flexible in their application of this power. Reference has already been made to orders relating to the scope of examination. ${ }^{117}$ Several rulings deal with the taking of depositions at distant places. In Clair v. Philadelphia Storage Battery Co. ${ }^{\mathrm{xr} 8}$ the court ordered that the deposition of a material witness be taken at

${ }^{109}$ Bough v. Lee and Price v. Levitt, discussed at pp. 303-5 supra.

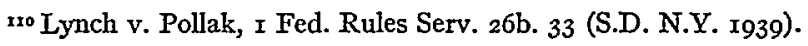

${ }_{x x} \mathrm{P} .3^{\mathrm{x}} 3$ supra. $\quad{ }^{2 x 2}$ See Pike and Willis, op. cit. supra note 9 , at $1442-3$.

113 I Fed. Rules Serv. 26b. 22 (S.D. N.Y. 1939).

${ }^{x \times 4}$ Unlandherm v. Park Contracting Co., 26 F. Supp. 743 (S.D. N.Y. I938); F. \& M. Skirt Co. v. A. Wimpfheimer \& Bros., 25 F. Supp. 898 (Mass. I939). But cf. Coca Cola Co. v. DixiCola Laboratories, 30 F. Supp. 275 (Md. I939).

${ }_{135}$ Penn v. Automobile Insurance Co., discussed at pp. $3^{15-16}$ supra.

${ }^{216}$ Hammond, Some Changes in the Preliminary Draft, 23 A.B.A.J. 629, 63I (I937).

217 P. 302 supra.

${ }_{118}{ }_{27}$ F. Supp. 777 (E.D. Pa. I939). 
Philadelphia (the place of trial) rather than at Douglas, Arizona, but it recognized that the consent of the deponent would be necessary. Costs of transportation were ordered to be taxed as costs. In another case, in which oral depositions were to be taken in Italy, the court ordered that, if the adverse party could not afford to be represented at the taking, he might submit written interrogatories after inspecting the transcript of the testimony. ${ }^{\mathrm{Ix}}$ Winograd Brothers v. Chase National Bank ${ }^{\mathrm{r20}}$ involved converse facts: depositions of witnesses in China were to be taken on written interrogatories; the opposing party secured leave to cross-examine the witnesses orally, each party to bear his own costs. In Fall Co. v. Yount-Lee Oil Co ${ }^{\text {I2I }}$ the plaintiff filed lengthy and numerous interrogatories dealing with the family relationship of two witnesses. The defendant stated that it was unable to prepare effective cross-interrogatories to such questions. The court held, under Rule $3 \mathrm{I}(\mathrm{d})$, that the matter would be more expeditiously handled if oral examination were had.

\section{USE OF DEPOSITIONS}

Rule 26(d), dealing with the use of depositions, was rather thoroughly analyzed in our earlier articles, ${ }^{122}$ in which we pointed out that depositions may be used only against persons who have received notice of the taking; that either party may use a deposition duly taken; and that an advanced position had been taken in the new rule with respect to the use of parts of a deposition. We also raised a query as to the use of depositions after removal to a federal court.

Judicial interpretation of Rule 26(d) has been scant. Two interesting oral opinions involving the anti-trust prosecution of the Aluminum Company of America have been reported. In one, Judge Caffey held that, even if the attorneys for certain defendants knew that depositions were being taken, the depositions might not be used against their clients where the attorneys had no reason to suspect that they were intended to be so used. ${ }^{123}$ On the following day an interesting colloquy occurred between the judge and counsel over the interpretation of the phrase "other relevant parts" found in Rule $26(\mathrm{~d}) .{ }^{\mathrm{x} 24}$ The deponent had answered a

129 The Italia, 28 F. Supp. 309 (E.D. N.Y. 1939).

r20 I Fed. Rules Serv. 3Id.23, Case No. I (S.D. N.Y. r939).

${ }^{12 x}{ }_{24}$ F. Supp. $76_{5}$ (E.D. Tex. 1938).

${ }_{22}$ Pike and Willis, op. cit. supra note 9 , at $x 443-5$; Pike, op. cit. supra note 9 , at 7,9 .

I23 United States v. Aluminum Co. of America, I Fed. Rules Serv. 26d.23 (S.D. N.Y. I939).

124 "If only part of a deposition is offered in evidence by a party, an adverse party may require him to introduce all of it which is relevant to the part introduced, and any party may introduce any other parts." Rule 26 (d) (4). 
number of questions by stating that he "had no knowledge" of the facts. Government counsel, who had offered the deposition, contended that a negative answer was not "relevant" and therefore need not be read. But Judge Caffey held that even if the negative answers might not impair the deponent's previous testimony, they were "relevant" and therefore should be read. ${ }^{25}$

Another decision holds that depositions taken in a state court prior to removal are admissible in federal court; ${ }^{\mathrm{r26}}$ but it appears that the trial took place before the new rules became effective.

A minor question concerning the use of depositions as admissions is raised in a recent decision of the Circuit Court of Appeals for the Second Circuit. ${ }^{27}$ The plaintiff wished to prove certain admissions by an officer of the defendant corporation at the taking of his deposition. The lower court refused to permit testimony by one who heard the admissions, but required the entire deposition to be put in evidence and extracts therefrom to be read. On appeal the court said:

Since the plaintiff was not precluded from getting the admissions into evidence, it is difficult to see wherein he suffered any prejudice. But in any event, the procedure adopted is justified under Rule 26(d) ....

The procedure is perhaps "justified," but is it the only proper one? The answer would seem to be in the negative. The deposition is being used as evidence not in the sense that it is a substitute for the deponent himselfthe usual case-but simply as an admission of a party. ${ }^{\mathbf{2} 8}$ Normally anyone who hears an admission may testify as to it, and Rule $26(\mathrm{~d})(2)$, permitting the use of an adverse party's deposition "for any purpose," should be regarded not as exclusive, but simply as intended to minimize controversy over whether a particular statement is or is not an admission. There is substantial authority for the view that a deposition may be used to prove an otherwise inadmissible prior contradictory statement, ${ }^{129}$ and

r25 United States v. Aluminum Co. of America, I Fed. Rules Serv. 26d.52 (S.D. N.Y. I939).

${ }^{126}$ Cervin v. W. T. Grant Co., roo F. (2d) I53 (C.C.A. 5th I938).

${ }_{\text {I27 }}$ Buder v. New York Trust Co., I07 F.(2d) 705 (C.C.A. 2d 1939). Accord: Dawson Town \& Gas Co. v. Woodhull, 67 Fed. 45I (C.C.A. 8 th 1895 ).

${ }^{228}$ The distinction between use as testimony and use as admissions is clearly pointed out in Napier v. Bossard, IO2 F. (2d) 467 (C.C.A. 2d I939).

${ }^{129}$ Charlton v. Kelly, ${ }_{5} 6$ Fed. 433 (C.C.A. 9th I907) (deposition in different action); Nash v. Yellow Poplar Lumber Co., rog Va. I4, 63 S.E. I4 (rgo8) (same); Chalmers v. United R. Co. of St. Louis, r53 Mo. App. 55, r3 I S.W. 903 (I9I0) (not filed); Farrar v. Metropolitan St. R., 249 Mo. 210, I55 S.W. 439 (Igr3) (unsigned); Lanigan v. Neely, 4 Cal. App. 760, 89 Pac. 44I (Ig07) (same). Contra: New York Life Ins. Co. v. Neasham, 250 Fed. 787 (C.C.A. gth I9r8) (same). 
some courts even require testimony as to what was said, rather than allow the deposition itself in evidence. ${ }^{\mathrm{I} 30}$

\section{DEPOSITIONS TO PERPETUATE TESTIMONY}

Only one reported case has construed Rule 27 , relating to depositions to perpetuate testimony, but it throws light on the most debatable question raised by the Rule: whether the rule may be used for purposes of discovery before the filing of a complaint. In our previous article it was pointed out that the rule itself was not entirely clear and that state courts were not in agreement on the point. ${ }^{\mathrm{x} 3}$ Commentators also disagreed. Former Attorney-General Mitchell, a member of the advisory committee, stated that the committee did not intend the rule to be "misused" as a means of discovery. Professor Edson R. Sunderland agreed as to the intention, but expressed some doubt as to whether the rule might not be otherwise interpreted. ${ }^{x 2}$ Later, however, Professor Sunderland, without mentioning Rule 27, expressed his opinion that discovery might not be used as a direct aid in drawing a complaint. ${ }^{\mathrm{x} 33}$ Professor William W. Dawson, on the other hand, felt that Rule 27 might be so used. ${ }^{134}$

In Egan v. Moran Towing \& Transportation Co., ${ }^{\mathrm{T} 35}$ a petition seeking an inspection and survey of a tugboat was filed under Rule 27 in connection with a contemplated suit for wrongful death occasioned while the decedent was employed on the tug. The request was denied, Judge Hulbert saying:

It is quite clear that the petition does not seek to perpetuate the testimony of any person within the purview of Rule 27 and that it cannot be entertained under Rule 34 since there is no action pending.

The petition states: "from the testimony thus far adduced before the Local Steamboat Inspectors it appears that the respondents were negligent and the tug was in an unseaworthy condition."

It would seem, therefore, that the petitioner should be able to frame a complaint and institute the action.

The case, of course, is not a direct ruling on whether or not Rule 27 may be used for discovery of a testimonial nature, because the question was not presented. It does, however, indicate a tendency to circumscribe

${ }^{\text {z30 }}$ Peppers v. St. Louis-San Francisco R. Co., $3 \times 6$ Mo. IIO4, 295 S.W. 757 (I927); Clark v. Gurley, 48 Tex. Civ. App. 274, Io6 S.W. 394 (Igo7).

r3x Pike and Willis, op. cit. supra note 9 , at 1 r93-4.

${ }^{{ }_{33} 3}$ Remarks of Prof. Edson R. Sunderland, Hon. William D. Mitchell and Mr. James A. Pike, Proceedings of Cleveland Institute on Federal Rules 292-3 (A.B.A. I938).

${ }^{233}$ Proceedings of New York Symposium on Federal Rules 255 (A.B.A. I939).

${ }_{34}$ Proceedings of Washington Institute 97 (A.B.A. 1939).

13526 F. Supp. 62I (S.D. N.Y. I939). 
the provisions of the rule along historical lines and to leave the party to the alternative of filing a skeleton complaint, securing discovery, then amending if necessary. ${ }^{36}$

\section{ADMISSION OF FACTS AND OF GENUINENESS OF DOCUMENTS}

Reference has already been made in several connections to the procedure for obtaining admissions of facts and the genuineness of documents under Rule 36. ${ }^{\mathbf{3} 7}$ Technically, this device is not so much a means of discovery as it is a simple method of narrowing issues and disposing of immaterial controversies-a supplement to the generalized type of pleadings contemplated by the new rules. But issue-formulation is also one of the objects of discovery, and the procedure is quite properly treated in a discussion of the subject.

Rule 36 has not as yet received a very extensive construction, perhaps because lawyers have not yet fully realized its possible uses. The principal controversies have arisen over the technical questions of whether the "facts," admissions of which may be requested, include facts not stated in documents, and whether the request to admit is subject to attack by motion prior to trial.

The first question should never have arisen. Rule $36(\mathrm{a})$ is, however, ambiguous in its reference to "the admission .... of the genuineness of any relevant documents described in and exhibited with the request or of the truth of any relevant matters of fact set forth therein." ${ }_{33} 8$ The first draft was more explicit. ${ }^{39}$ It seems clear that the intention was to extend the procedure to any matters of fact, whether stated in documents or not. The official form of notice to admit is so framed, ${ }^{140}$ but it took several decisions to settle the question. ${ }^{{ }^{4} \mathrm{I}}$

Where the facts concerning which admissions are sought are actually stated in documents, however, it may not be sufficient merely to present the documents with a blanket request for admission of all facts stated therein. It will be noted that the rule specifies that the facts must be "relevant." In a recent case in the Southern District of New York, the plaintiff requested the defendant to admit the genuineness, receipt, and

${ }^{x}{ }^{6}$ See Pike and Willis, op. cit. supra note 9 , at $I$ I93 -4 .

137 Pp. 309, 312-13 supra. ${ }^{13}$ Italics added.

${ }_{39}$ ".... . any specific relevant facts stated in such notice ...." Preliminary Draft, Rule 40 (a) (r936).

${ }^{240}$ Form 25.

${ }^{14 x}$ Walsh v. Connecticut Mut. Life Ins. Co., 26 F. Supp. 566 (E.D. N.Y. I939); McCrate v. Morgan Packing Co., 26 F. Supp. 8I 2 (N.D. Ohio I939); Nekrasoff v. United States Rubber Co., 27 F. Supp. 953 (S.D. N.Y. I939); Unlandherm v. Park Contracting Co., 2 Fed. Rules Serv. 36a.4I (S.D. N.Y. I940). 
truth of a certain letter and report. The letter was "a compound of statements of fact, self-serving declarations and opinions." Judge Leibell held that the request must specifically set forth the relevant matters of fact on which an admission was sought, and that the opposite party should not be required to winnow out the relevant matters..$^{x^{2}}$

The second question was left open by the rule, although the implication is that a party served with a request must deny or avoid at his peril and cannot secure an advance ruling on the propriety of the request. Some courts have assumed the power to entertain a motion to strike or limit a request to admit, ${ }^{x_{43}}$ but where the question has been squarely presented a ruling has been evolved-in rather an odd fashion-that such a motion will not lie. In Walsh v. Connecticut Mutual Life Insurance Co. ${ }^{\mathrm{x} 4}$ Judge Moscowitz implied that there could be no preliminary determination of the propriety of the request. The Walsh case was cited in McCrate $v$. Morgan Packing Co., ${ }^{x 5}$ but the "motion to strike" passed upon in that case was apparently overruled on the merits. But in Nekrasoff $v$. United States Rubber Co. ${ }^{\mathrm{4} 6}$ Judge Hulbert, who had previously entertained such a motion without discussion of the point, relied on the $\mathrm{MCCrate}$ case and held that a request under Rule 36 was not subject to a motion to strike. Three later decisions have followed the holding in the Nekrasoff case. ${ }^{{ }^{4} 6 \mathrm{a}}$ This rule, followed in other jurisdictions which have passed on the question, ${ }^{x / 7}$ seems preferable. ${ }^{x / 8}$ The purpose of the rule is to expedite litigation, but if every request to admit is to be subject to a motion to strike, the courts will be impeded rather than helped. ${ }^{I 49}$ For this same reason the procedure followed in Kraus v. General Motors Co..$^{150}$ seems objectionable. The defendant having failed to respond to the plaintiff's request to admit, the plaintiff submitted an order that the matters be "deemed admitted." While the order was submitted ex parte, Judge Leibell ordered

${ }^{242}$ Kraus v. General Motors Co., 29 F. Supp. 430 (S.D. N.Y. 1939).

${ }^{343}$ Booth Fisheries Co. v. General Foods Co., 27 F. Supp. 268 (Del. I939); Treasure Imports v. Henry Amdur \& Sons, I Fed. Rules Serv. 36a.22, Case No. 2 (S.D. N.Y. I939).

${ }^{244} 26$ F. Supp. 566 (E.D. N.Y. I939).

${ }^{445} 26$ F. Supp. 812 (N.D. Ohio 1939). $\quad{ }_{246}^{27}$ F. Supp. 953 (S.D. N.Y. I939).

${ }_{x} 6 \mathrm{a}$ Modern Food Process Co. v. Chester Packing \& Provision Co., 2 Fed. Rules Serv. 36a.4I (E.D. Pa. 1939); Unlandherm v. Park Contracting Co., 2 Fed. Rules Serv. 36a.4I (S.D. N.Y. 1940); S. E. C. v. Payne, 2 Fed. Rules Serv. $36 a .4 I$ (S.D. N.Y. r940).

${ }_{247}$ Banca Nazionale di Credito v. Equitable Trust Co. of New York, 22r App. Div. 555, 224 N.Y. Supp. 617 (r927); Crawford v. Chorley, r8 Weekly Notes, pt. r, at I98 (Eng. r883).

${ }_{18}^{8}$ See Method of Attacking Notice to Admit Facts, I Fed. Rules Serv. 36a.4I (1939).

${ }^{14}$ See Jenner and Schaefer, The Proposed Illinois Civil Practice Act, I Univ. Chi. L. Rev. 49,57 (1933).

${ }^{x 50} 29$ F. Supp. 430 (S.D. N.Y. x939). 
that notice be given. The defendant submitted affidavits and the propriety of the request was tried out on the merits.

\section{PHYSICAI AND MENTAL EXAMINATION OF PARTIES}

Rule 35 , providing for physical and mental examination of parties, is an innovation in federal procedure. ${ }^{15 x}$ To compel a litigant, at the behest of the opposing party, to submit his person to a physician's inspection, has been regarded by many as an outrageous invasion of privacy. To be sure, it was generally conceded that it was within the power of the legislature so to provide, ${ }^{152}$ but there were those who regarded the matter as impinging too closely on substantive rights to fall within the power of the Supreme Court under the Enabling Act. ${ }^{\mathrm{T} 3}$

A recent decision of the Circuit Court of Appeals for the Seventh Circuit, however, seems to settle any doubts as to the validity of the rule. The question was squarely presented to the court by an appeal from a contempt citation for refusal to comply with an order for physical examination. Regardless of any previous pronouncements of the Supreme Court, ${ }^{154}$ Circuit Judge Major held, the question should be considered closed by the fact that both the Supreme Court and Congress in promulgating and accepting the rule had evidently construed it as not affecting substantive rights. ${ }^{\mathrm{I}}{ }_{4 \mathrm{a}}$

An interesting feature of the case is the fact that the party had been imprisoned for contempt. Rule $37(\mathrm{~b})$, which provides sanctions for the various discovery rules, does not mention contempt in connection with Rule 35 (as it does in reference to refusal to give a deposition) and expressly provides that an order of arrest shall not issue for disobedience of an order for a physical examination. No question seems to have been raised as to the appropriateness of the punishment. But while the language of Rule 37 is none too clear on this point, it is doubtful that it would be construed as depriving the court of its inherent power to enforce its own orders by contempt proceedings.

The constitutional point was apparently assumed in Wadlow v. Humberd ${ }^{\text {,5s }}$ but the decision goes far toward a more restricted application of

Isr See Dobie, The Federal Rules of Civil Procedure, 25 Va. L. Rev. 26r, 280 (I939).

${ }^{252}$ Lyon v. Manhattan R. Co., ${ }_{42}$ N.Y. 298, 37 N.E. II3 (1894); McGovern v. Hope, $6_{3}$ N.J. Law 76, 42 Atl. 830 (I899). Federal courts "conformed" to such statutes. Camden \& Suburban R. Co. v. Stetson, I77 U.S. I72 (rgoo).

I53 See Hearings before Subcommittee on Judiciary, $75^{\text {th }}$ Cong. 3 d Sess., at 29-30, May I9, I939. But cf. 34 Ill. L. Rev. I03, I05, n. I7 (I939).

${ }_{154}$ Cf. Union Pacific R. Co. v. Botsford, I4I U.S. 250 (r89r); Camden \& Suburban R. Co. v. Stetson, I77 U.S. I72 (I900).

x54a Sibbach v. Wilson \& Co., ro8 F.(2d)4I5 (C.C.A. 7th I939).

${ }_{255} 27$ F. Supp. 210 (W.D. Mo. 1939). 
the rule than was probably intended. The action, a libel suit, was brought by Robert Wadlow, a "giant," against a doctor who had written an article concerning him in a medical journal. The essay contained certain comments on the plaintiff's physical and mental condition which he considered libelous, and the defendant's answer apparently pleaded the truth of the statements. Not surprisingly, the defendant sought a physical and mental examination of the plaintiff before trial. But the motion was denied. Historically, Judge Otis said, physical examination under statutes or rules of court seems to have been limited to actions for personal injury, and "this historical background does not support the motion." The rule itself, of course, contains no such limitation; it extends to all cases "in which the mental or physical condition of a party is in controversy." The answer to this, however, was simple: the mental or physical condition of a party cannot be "in controversy" in a libel suit. Or "to be a little more explicit, although not more accurate, perhaps I should say that the mental or physical condition of a party cannot be immediately or directly in controversy in a libel suit." As an illustration Judge Otis gave a case in which the defendant had said that the plaintiff had ten toes on each foot. The defendant pleaded truth. The only "matters in controversy," according to Judge Otis, are: (a) did the defendant make the statement and (b) is it true or false.

To the superficial view it may appear that the issue: "Is A's statement concerning $B$, that $B$ has ten toes on each foot, a true or a false statement?" is identical with the issue: "Has B ten toes on each foot?" Really the two issues are entirely different. The subject matter of issue No. $r$ is the truth or falsity of A's statement. The subject matter of issue No. 2 is the number of toes which B has on each foot.

It is unthinkable that the Rule should be given any such interpretation as is urged here by the defendant.....

The decision has been properly criticized. ${ }^{\mathrm{r} 56}$ Any "historical" basis which the rule might have would not seem to be worth much weight as against the unambiguous words of the rule itself. And it is clear that the decision in the Wadlow case really writes into the rule the words "immediately or directly [in controversy]." Of course, in the nature of things, the great majority of cases in which physical examinations are requested will be personal injury cases or insurance cases in which the condition of the party will be "immediately or directly" in controversy. But the Wadlow case demonstrates that the use of Rule 35 is not necessarily limited to such cases. It certainly would seem that pre-trial examination in the $W a d-$ low case might have been helpful to the preparation and trial of the action.

As yet Judge Otis' decision has been cited in no other opinion construing Rule 35 . It is to be hoped that other courts will be guided by a ${ }^{256} 34$ Ill. L. Rev. ${ }^{0} 3$ (x939). 
literal construction of the language of the rule. Since granting or denying the order is within the court's discretion, and since no appeal can be taken directly therefrom, ${ }^{\mathrm{I} 57}$ it should be possible to guard against possible abuse without emasculating the clear language of the rule.

Interesting in this connection is a recent order by Justice Adkins of the District Court for the District of Columbia. ${ }^{\mathrm{x} 8}$ An action was brought for separate maintenance of the plaintiff and her child. The defendant denied paternity. On the defendant's motion the court ordered the plaintiff and the child to submit to a blood-grouping test. No opinion was written, and the court did not indicate whether it considered Rule 35 to give it the power to make the order; but it was argued by counsel for the defendant that the rule applied to the case. The question is complicated, however, by the fact that the District of Columbia court, unlike other district courts, is a court of general jurisdiction; it was contended that the court therefore had inherent power to act as it did.

The question raises interesting problems under Rule 35. Can the physical condition of the mother and child be "in controversy" in a paternity case? And is a blood test properly within the term "physical examination"? A New York decision has allowed a blood test under a statute using the same words. ${ }^{\text {I59 }}$ But Rule 35 applies only to "parties," and the infant was not-nominally, at least-a party to the action. Can the term be expanded to cover persons not nominally parties to the action?

Other decisions construing Rule 35 are of little moment except as indicating that the courts will exercise a good deal of discretion in dealing with the matter. ${ }^{160}$ For instance, it has been held that the examining party has no absolute right to select his own physician over the protest of the other party. ${ }^{\mathrm{I} x}$

\section{SANCTIONS}

Rule 37 implements the various discovery devices with a truly amazing array of sanctions: costs and attorney's fees, orders dispensing with proof, orders forbidding the introduction of evidence, orders striking pleadings or staying proceedings or dismissing the action, judgments by default, contempt, and arrest. While the very variety of the possible courses of

s57 Bowles v. Commercial Casualty Ins. Co., IO7 F. (2d) I69 (C.C.A. 4th I939).

${ }^{158}$ Beach v. Beach, File No. 2897 , D.D.C. Oct. 3, I939. Petition for special appeal from the order has been granted by the Court of Appeals for the District of Columbia. (Information from counsel.)

${ }^{159}$ Hayt v. Brewster, Gordon \& Co., I99 App. Div. 68, Igr N.Y. Supp. I76 (I92I), construing N.Y. Civil Practice Act, $\S 306$.

r6o Cf. Strasser v. Prudential Ins. Co., r Fed. Rules Serv. $35^{2.42}$ (W.D. Ky. I939); Kelleher v. Cohoes Trucking Co., 25 F. Supp. 956 (S.D. N.Y. 1938).

I6x The Italia, 27 F. Supp. 785 (E.D. N.Y. r939). 
action gives the court a wide range of discretion, a zealous judge could make discovery a word of terror. So far, however, the tendency is apparently in the opposite direction. The courts, exhibiting a generous attitude toward the recusant party, have deemed it better to withhold the thunderbolt on condition of future compliance than to foreclose a determination of the matter on the merits.

Walsh v. Connecticut Mutual Life Insurance Co., ${ }^{162}$ although it did not directly involve Rule 37 , is indicative of this tendency. The plaintiff having failed to respond to a notice to admit, a motion for summary judgment was made. Judge Moscowitz, while conceding that the circumstances authorized a summary judgment, denied it on the ground that the rules were still new and unfamiliar and that the remedy was somewhat too drastic where the parties, acting in good faith, sought a construction of the rules. ${ }^{163}$ Similarly, two recent cases have refused to enter a default judgment for failure to respond to interrogatories or to give a deposition; the denial of the motion was, of course, conditioned on the party's compliance with the request. ${ }^{164}$ None of the cases involved any contumacious conduct, and the disposition of the matter by the respective courts was clearly proper; the cases should therefore not be taken as "drawing the teeth" of the discovery rules. The jail sentence imposed for refusal to submit to a physical examination in the case referred to above $\mathrm{e}^{\mathrm{x} 65}$ shows that the teeth are still there.

Soon after the effective date of the rules, one of us was giving a lecture on the new discovery procedure. Afterwards, one of the lawyers in attendance expressed himself somewhat as follows:

Everything you have said is very interesting, but I think you're going to find that things will go on much as before; lawyers are going to go on preparing for trial just as they always have and will make little use of the discovery rules; and you can be sure that judges aren't going to carry out the rules literally to allow a lawyer to pry into his opponent's case.

Very little could then be said in response to such a position; but the decisions of the past year have furnished a conclusive answer. The federal practitioners are using the new discovery procedure; note the abundance of litigation. And, remarkably enough, the judges, casting off the old shackles, have applied the new scope of examination almost literally. Federal discovery is in operation.

${ }^{262} 26$ F. Supp. 566 (S.D. N.Y. 1939).

${ }^{263}$ See also McCrate v. Morgan Packing Co., 26 F. Supp. 8I2 (N.D. Ohio I939).

${ }_{364}$ Dann v. Compagnie Générale Trans-Atlantique, 29 F. Supp. 330 (E.D. N.Y. I939); Madison v. Cobb, 29 F. Supp. 88I (M.D. Pa. I939).

${ }^{665}$ Sibbach v. Wilson \& Co., Inc., discussed at p. 324 supra. 